DE DE GRUYTER

OPEN

DOI 10.1515/pesd-2015-0033

PESD, VOL. 9, no. 2, 2015

\title{
ASPECTS REGARDING THE ANTHROPIC INFLUENCE ON THE “MOVILA LUI BURCEL" PROTECTED AREA (VASLUI COUNTY)
}

\author{
Irimia Irina $^{1}$, Ambrono Valentina $^{1}$, Stratu Anişoara ${ }^{1}$
}

Key words: anthropic influence, protected area, rare species

\begin{abstract}
This paper underlines some aspects regarding the anthropic influence on the "Movila lui Burcel" protected area. There were done some periodical displacement and observations in the field (2012-2014); there were identified anthropic factors with negative influence on the protected area; there were described the effects of the action of these factors. The anthropic factors with negative influence identified on the territory of the protected area are: the existence of the plantations of black locust (Robinia pseudoacacia) and Russian olive (Elaeagnus angustifolia); unreasonable grazing; presence of wastes and some fire hearths. The effects of the anthropic factors identified are represented by: modifications of the habitat with serious consequences on the existence and perpetuation of rare and vulnerable species included on the red lists; degrading of landscape.
\end{abstract}

\section{Introduction}

A known way to preserve in situ the biodiversity is to create the system of protected areas. The network Nature 2000 combines the objectives to preserve the biodiversity with those of durable social and economic development (Mănoiu et Brânzan, 2013).

At European and also national level, biodiversity is affected by a series of anthropic factors (urban expansion, development of the infrastructure, overexploiting of the ecosystems, changes in the use of fields, etc.) and natural (climatic changes). Among the consequences of these factors are mentioned: destruction, degrading and fragmenting of the habitats; modification of landscape; reduction in number and disappearance of some species (Planul de acţiune al UE privind biodiversitatea, 2010; Raport naţional privind starea mediului - anul 2012).

\footnotetext{
${ }^{1}$ Faculty of Biology, “Alexandru Ioan Cuza” University of Iaşi, Romania
} 
According to the Plan of action of the European Union regarding bio-diversity (2010), the majority of the natural areas existent in Europe, including the areas within the network Nature 2000, are exposed to threats (pollution, intensification of using the fields, etc.). Currently, it is considered that the majority of the ecosystems in Europe are in a degraded state.

It is known that the maintaining the structural and functional integrity of the ecosystems within the protected areas allows them to face the anthropic and natural pressure, thus influencing favourably also the ecosystems in the not protected areas.

Among the types of protected areas at natural level, the natural reserves are the most numerous. The "Movila lui Burcel" hill has been declared botanical natural reserve in 1973; it is unique or one of the few steppe reserves in Romania, protecting and preserving thermophilic floristic elements of special scientific importance (Dobrescu et Leocov, 1982).

"Movila lui Burcel" is a protected area of national interest (natural reserve of botanical interest); it occupies a surface of 12 ha (Anexa I a Legii nr. 5/2000, poziţia 2775). It is located on the territory of the commune Micleşti in Vaslui County. According to the classification I.U.C.N., the natural reserves belong to the category IV - area of habitat/species administration (OUG 57/2007; Primack et al., 2002).

Since 2007, the protected area "Movila lui Burcel" has been declared site of community importance (ROSCI0117) within the network Nature 2000 (OM MMDD nr. 1964/2007), for three species of community interest: two species of cormophytes (Echium russicum and Iris aphylla ssp. hungarica), a species of mammals (Spermophilus citellus); the type of habitat 62C0* (Ponto-Sarmatic steppes). The geographic coordinates of the SCI are: $46^{\circ} 50^{\prime} 59^{\prime \prime} \mathrm{N}$ and $27^{\circ} 48^{\prime} 12^{\prime \prime} \mathrm{E}$ (Mănoiu et Brânzan, 2013).

Apart from the type of habitat and the species protected at European level, within the reserve there are many species of rare plants from Moldavia's flora; these species there are currently included on the red lists in Romania. The rare taxa found on the territory of the reserve are: Adonis vernalis L., Adonis volgensis Steven ex DC., Adonis x hybrida C. F. Wolff ex Nyman, Allium moschatum L., Astragalus dasyanthus Pall., Astragalus glaucus M. Bieb., Astragalus pubiflorus DC., Centaurea marschalliana Spreng., Cirsium serrulatum (M. Bieb.) Fisch., Kengia bulgarica (Bornm.) Packer, Crocus reticulatus Steven ex Adams, Dianthus capitatus Balb. ex DC., Galium volhynicum Pobed., Goniolimon besserianum (Schult. ex Rchb.) Kusn. Hyacinthella leucophaea (K. Koch) Schur, Iris aphylla L., Iris pontica Zapal., Salvia aethiopis L. and Salvia nutans L. (Horeanu et Cogean, 1981, Dobrescu et Leocov, 1982, Irimia et Mânzu, 2013). The taxa are classified in one of the sozologic categories on the national red lists elaborated by: 
Oltean et al., 1994; Boşcaiu et al., 1994; Dihoru et Dihoru, 1994; Negrean, 2001; Sârbu et Chifu, 2003; Oprea, 2005; Dihoru et Negrean, 2009.

On the territory of the protected area, on the top of the "Movila lui Burcel" hill, there is a statuary group which fragmented/reduced the surface occupied by its characteristic vegetation. Also, on the slopes with the steppe vegetation (Pontic, sub-Mediterranean and continental elements), as well as some very rare species, which should be protected, were planted the wooden species Robinia pseudoacacia (black locust) and Elaeagnus angustifolia (Russian olive), possibly to reduce the process of erosion of the soil and the landslide. The growth and development of these two species in the natural habitats prevent the natural succession of the vegetation, fact that can determine the elimination of the some rare species of the territory of the reserve in the case appropriate measures are not taken (Sîrbu et Oprea, 2011).

This paper has as purpose to underline some anthropic factors with negative influence on the "Movila lui Burcel" protected area.

\section{Material and methods}

From the geographic point of view, the territory of the "Movila lui Burcel" protected area is part of the Moldavian Central Plateau. It is the top of a hill, with an inclination of $15-25^{\circ}$ (Mănoiu et Brânzan, 2013), presenting a rugged relief that led to several landslides and the accentuation of the phenomenon of erosion (Dobrescu et Leocov, 1982). The maximum altitude is $273 \mathrm{~m}$. The main types of soil present in the protected area are: leached chernozem characteristic for the plane reliefs, the carbonated chernozem formed on the intensely eroded slopes, semi-carbonated chernozem and the regosols on the slopes with severe erosion (Mănoiu et Brânzan, 2013). The area is characterised by a continental climate of east-European type, with an average annual temperature of $8.4^{\circ} \mathrm{C}$ and the quantity of annual precipitations between 550-570 mm (Costică, 2012).

Field surveys and observations were made between 2012 and 2014. We identified the anthropic factors with unfavourable influence on the protected area; we followed the modifications on flora, vegetation and landscape.

\section{Results and disscusions}

The field surveys and observations done in the area taken into study underlined that the uniqueness of this protected area is influenced negatively by a series of anthropic factors.

Anthropic factors with negative influence identified on the territory of the protected area are:

Plantations of black locust (Robinia pseudoacacia) and Russian olive (Elaeagnus angustifolia) existing in the protected area (Fig. 1). These species are 
placed as follows: Robinia pseudoacacia on slopes with exposure N-NE, S-SW, and Elaeagnus angustifolia on slopes W-SW (Costică, 2012). These two species are included on the list of invasive species at global level (Robinia, Elaeagnus http://www.issg.org).

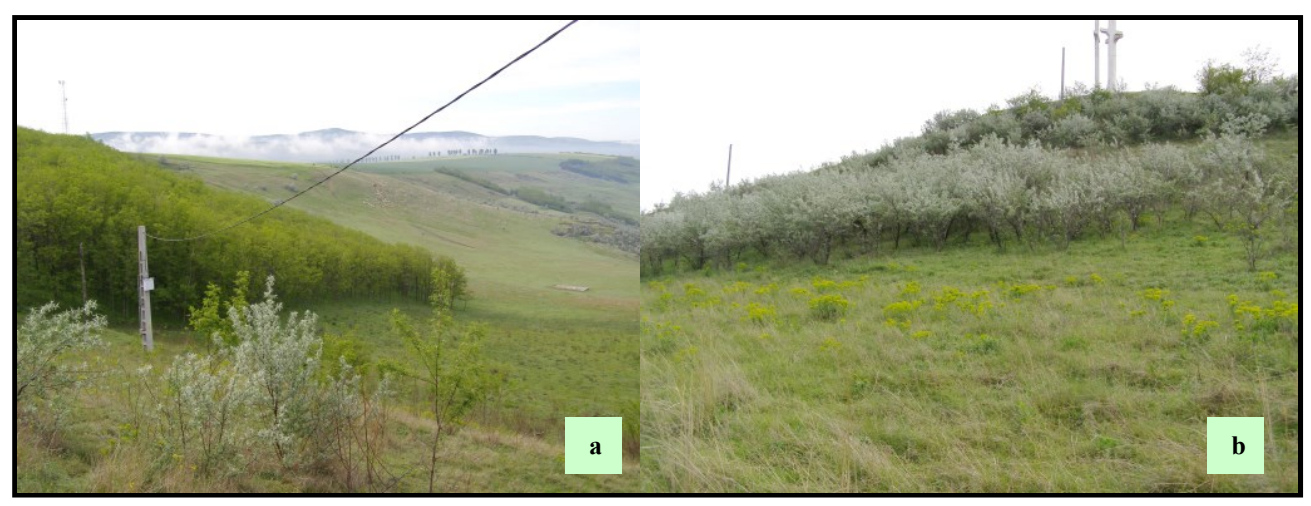

Fig.1. Plantations of Robinia pseudoacacia (a) and Elaeagnus angustifolia (b)

Robinia pseudoacacia is one of the most common species of invasive plants in Europe (Sârbu et Oprea, 2011). In Romania the species was introduced in 1750 (Haralamb, 1967); in Moldova, the first mentioning dates from the beginning of the $19^{\text {th }}$ (Sîrbu et Oprea, 2011). It is a heliophile species, moderately thermophile, xero-mesophile to mesophile, amphitolerant to $\mathrm{pH}$, psamophile (Pârvu, 2000); it develops well on light, permeable, well-drained, wet, wet-dry, fertile soils (Nyárádi, 1957; Dumitriu-Tătăranu, 1960; Pârvu, 2000). It is a pioneer species; it has the capacity to fix the atmospheric nitrogen by symbiosis, reason for which it can colonize soils very poor in nutritive substances. The first plantations of black locust were formed in some areas of the country to fix and improve the degraded soils. Then, together with using the species in forest curtains of protection, it was extended and naturalized on large areas in all the regions of the country, because of the rhythm of rapid growth and intense capacity to form sprouts and root sucking (Dumitriu-Tătăranu, 1960; Pârvu, 2000; Sîrbu et Oprea, 2011).

The studies done underlined the fact that the plantations of black locust represent a threat in preserving the native vegetation in some area. On long term, they contribute to reducing the flora diversity. The reasons for this effect are multiple: the dry soil and the reduction of water and nutrient availability, because of the radial system very well developed; by rapid growth, by intense capacity to form sprouts and root suckers; by very intense transpiration; by shadowing the soil, it contributes to the disappearance of the heliophile species; fixing the atmosphere nitrogen because of root nodosities favours the elimination of native species and 
installation of some nitrophile species (Dumitriu-Tătăranu, 1960; Haralamb, 1967; Pârvu, 2000; Enescu et Dănescu, 2013; Kastler et Samimi, 2013); it competes with the native species in attracting the pollinators; the allelopathy effect due to some phenolic compounds (Sârbu et Oprea, 2011).

Dobrescu et Leocov (1982) mentioned the existence of the black locust plantations in the "Movila lui Burcel" natural reserve and recommended to limit the extension of these plantations because of self seeding.

From the perspective of preserving biodiversity it is considered that the black locust plantations should be monitored attentively (Enescu et Dănescu, 2013), especially the ones located in the vicinity of the protected areas or in protected areas (such as the case of the protected area taken into account in this study).

Elaeagnus angustifolia was introduced as ornamental, melliferous plant, as well as to stabilize the degraded fields, realize the forest curtains of protection against wind and snow; it was gradually extended from the culture and it became invasive in Europe (Dumitriu-Tătăranu, 1960), as well as in North America (Katz et Shafroth, 2003). The first mentioning in Moldova was done by Czihack in 1836 (as cultivated species) and then by Szabo in 1841 in Iaşi (Sîrbu et Oprea, 2011).

It is a heliophile species, but somewhat shade tolerant; mesoxerophilemesophile; mesotrophic; resistant to drought because of the root system welldeveloped, but also the morpho-structural adaptations of the leaves. Even though it is a species tolerant for the soil conditions (texture, fertility, soil reaction); it grows best in deep sandy soils, also tolerates a high content of salts in the soil (tolerant halophile) (Dumitriu-Tătăranu, 1960; Pârvu, 2005; Sîrbu et Oprea, 2011).

The species presents: deep roots; rapid growth when young; high capacity to regenerate by sprout and root sucking (Sîrbu et Oprea, 2011). The roots form nodosities because of the symbiosis with fixing actinomycetes of nitrogen (Frankia elaeagni), but also present ectotrophic mycorrhizae; because it enriches the soil in nitrogen, it favours the installation of nitrophile weeds (Katz et Shafroth, 2003). Because of the ecological tolerance, it can invade different habitats, competing with the native species in the habitats invaded for the factors of environment (light, water, nutrients) (Collins, 2002).

Sârbu et Oprea (2011) mention in Moldova the negative influence of this species, cultivated against erosion, which extended from these plantations to the detriment of the xerophile meadows. The authors mention the case of the "Movila lui Burcel" protected area, where Elaeagnus angustifolia and Robinia pseudoacacia were planted "on the slopes with steppe vegetation with very rare flora elements, which should be protected, but which will be surely eliminated by the development of these two invasive species." 
In the Plan of action of the European Union regarding biodiversity (2010) it is mentioned the fact that the invasive species represent an important cause to reduce biodiversity.

$>$ Irrational grazing/overgrazing on the protected area (during inappropriate periods of time: March-July, rainy periods), especially on the slopes with exposure N-NW and W-SW, by flock of small herbivorous animals (sheep and goats). On the pastures near the protected area usually graze several flocks of small herbivorous animals. These pastures have law productivity (Dobrescu et Leocov, 1982), and in the period of study we noticed that they were overgrazed.

During the field surveys in 2013, we did not notice grazing flocks, but we identified several signs representing proof of inappropriate grazing (paths made by animals, traces of animals on soil still moist, many animal excrements, wool stuck on black locust twigs, grazed plants) (Fig. 2). In spring 2014, with removing the fence delimiting the protected area from the pastures nearby, the risk of exposure to irrational grazing increased (Fig. 3), in the conditions of not observing some measures regarding grazing in the protected areas of national interest.

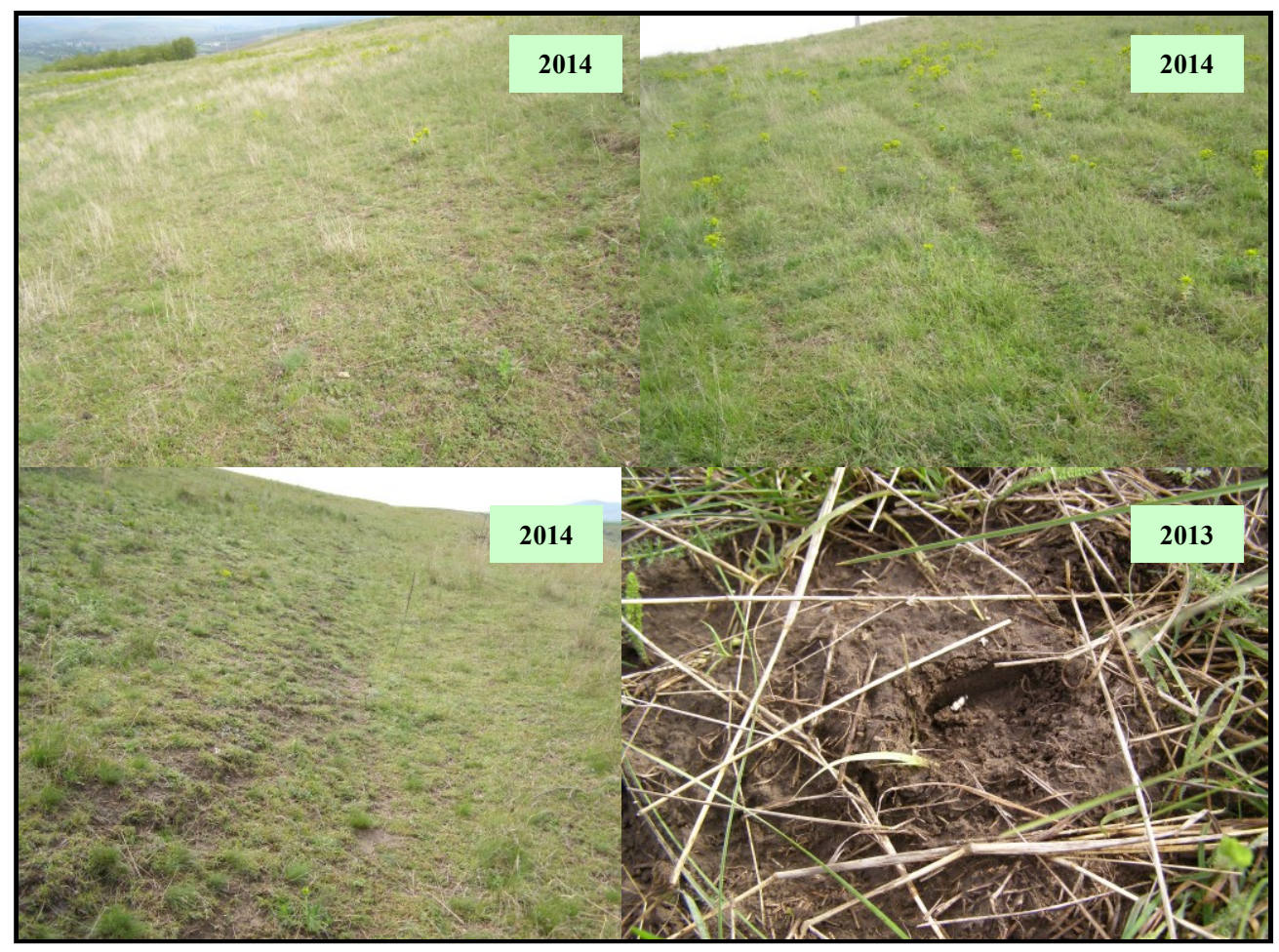

Fig. 2. Degradation of the habitat by the irrational grazing 
The negative effects of the irrational grazing/overgrazing noticed on the protected area are: destruction of vegetation by consumption of aerial parts of the plants; treading the soil by moving the animals; emptying the underground parts of the plants of stepping on them; paths left from frequent movement of the animals that favour the installation of the process of erosion of the soil; the frequent movement of animals and the dejections left by them, favours the growth and development of harmful species (Eryngium campestre, Carduus acanthoides etc.) and toxic (Euphorbia glareosa etc.), fact which determines the modification of the floristic composition of the vegetal cover of the meadow.

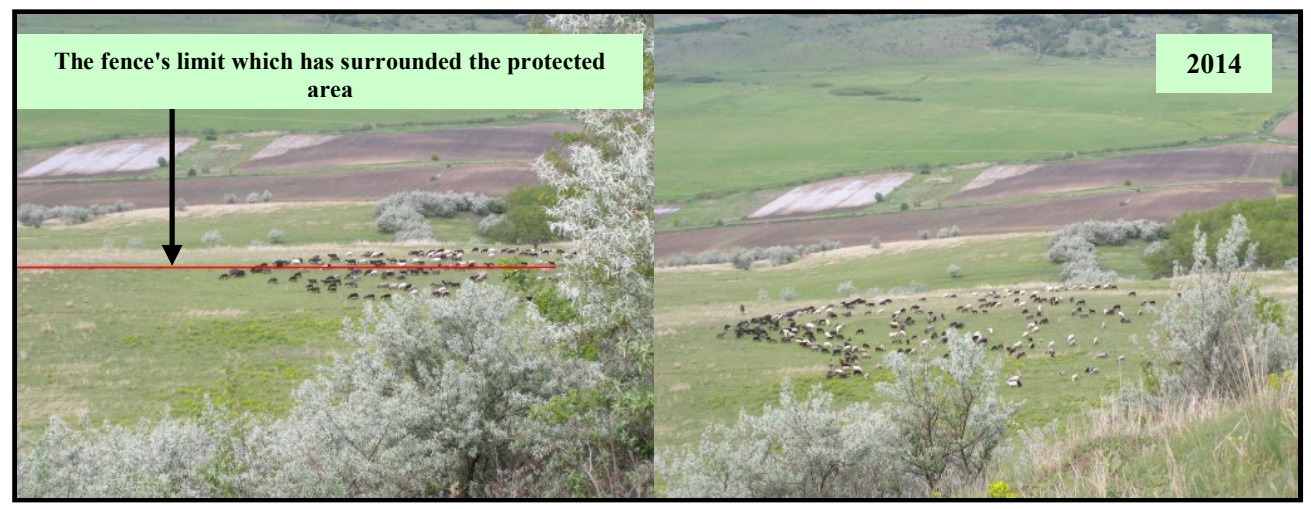

Fig. 3. Grazing near the protected area and on the protected area

The destruction of the vegetation contributes to the reduction of the populations of protected species, but also other species in the phytocenosis. From the observations in the field done in spring 2014, it was noticed that some rare species are affected by grazing: Iris pontica, Centaurea marschalliana, Astragalus dasyanthus (Fig. 4).

Iris pontica is a perennial species by rhizome, heliophile, which develops on dry neutral soils, on sunny hills with grass. According to Dihoru and Negrean (2009), Iris pontica is a species critically endangered. The area where this species grows is from Transylvania to Central Asia. In Romania, the species is found in some places in Transylvania (Dihoru et Negrean, 2009), and in Moldova only in the "Movila lui Burcel" naturale reserve (Irimia et Mânzu, 2013). In the area studied, the species Iris pontica grows in the phytocenoses edified by Festuca valesiaca which are dominant, the species being exposed to grazing by animals. Leaves are eaten early (vegetative phenophase) by animals and cannot assure anymore the organic substances necessary to the fructification, as well as 
166 Aspects regarding the anthropic influence on the "Movila lui Burcel" protected area

depositing in the rhizome (to maintain the viability in periods of dormancy and plant regeneration) (Fig. 4).

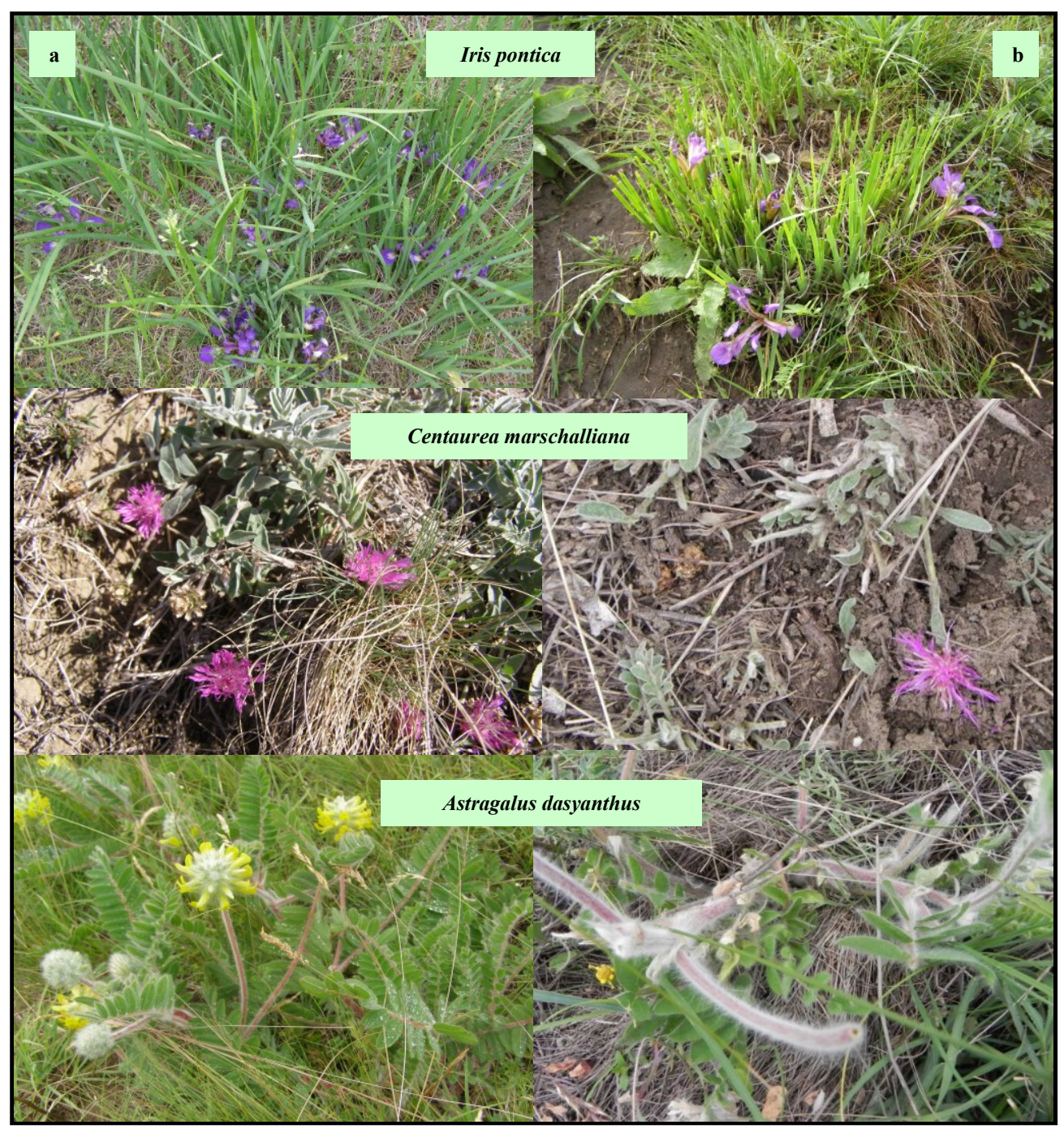

Fig. 4. Species included on the national red lists: a - not grazed (2013), b - grazed (2014)

Boşcaiu et al. (1994) mentioned that the direct pressure on the populations of plants determine the reduction of the possibilities for their regeneration.

Another Pontic element, rare in the flora of our country, affected by irrational grazing, is Centaurea marschalliana. It is a heliophile, thermophile, xerophile 
species, which grows on soils rich in calcium carbonate and reduced content of humus (Dobrescu et Leocov, 1982). The area of spreading this species is in Bulgaria, Moldova, Romania, Russia and Ukraine (Bancheva, 2008). In Romania, the species is found only in some counties in the east and south-east of the country (Sârbu et al., 2013). On the red lists in Romania, the species is classified in the category of the vulnerable species (Dihoru et Dihoru, 1994, Sârbu et Chifu, 2003), vulnerable/rare (Oltean et al., 1994), rare (Oprea, 2005). Because of the consumption of leaves, and the destruction of plants by stepping on them, because of grazing, the plants do not reach the phase of fructification, which is a risk for the species perpetuation. Even though it is perennial by rhizome (Prodan et Nyárády, 1964), the consumption of the aerial part and the destruction of the vegetation around, as well as the compaction of the soil (Fig. 4) represent factors that determine the numeric reduction of the population.

Pricop et al. (2010) identified two populations (with a reduced number of individuals) of Centaurea marschalliana on the territory of the "Movila lui Burcel" protected area and underlined the anthropic factors representing a risk for these populations. In their opinion, these factors were represented by the monachal constructions, the statuary groups that reduce the surface occupied by the steppe vegetation, as well as the ways of access to them.

In 1982, Dobrescu et Leocov mention the fact that this species formed dense populations, were in full expansion, the species not being able to cope with the cenotic competition.

Another rare species, Pontic-Pannonian, affected by grazing is Astragalus dasyanthus. It is a perennial species, heliophile, thermophile, xerophile (Sârbu et al., 2013), which grows on sandy soils, stones or calcareous, with reduced content of humus; on herb coasts, preferring South, South-West and West slopes (Ermolaev, 2007). According to Bădărău et al. (2000), the area of this species is typically fragmented: the middle and inferior basin of Volga, the steppe and silvostepa in the North of the Black Sea, the woody steppe of the Pannonian Field, the North of the Balkan Peninsula. In Romania, the species is found in several enclaves of areal: Moldova Plateau, the range of mountains in North Dobrogea, the Transylvania Depression, and in one locality in Mehedinţi County.

On the red lists in Romania the species is mentioned in the category of rare species (Oltean et al., 1994; Dihoru et Dihoru, 1994; Negrean, 2001; Sârbu et Chifu, 2003). We noticed that individuals in the population of the species were grazed before blooming/in the period of blooming (Fig. 4), which reduces the percentage of survival of the species, and of maintaining the population in the protected area. The populations of this species are placed on the slopes with West and South-West exposure, slopes under risk of irrational grazing/overgrazing, thus making vulnerable the populations of Astragalus dasyanthus. 
In the literature in the field, there are studies regarding the reduction of the populations and the degrading of the habitat of this species, caused especially by overgrazing, as well as studies regarding the necessity of in situ preservation. According to Bădărău et al. (2001) Astragalus dasyanthus together with two other species of the genus Astragalus (A. excapus L. ssp. transsilvanicus (Barth) Jáv. and $A$. asper Wulf.) are considered indicator species for the xerophile steppe phytocenoses well preserved; these species present a very low resistance to the anthropic impact on the phytocenoses (especially by overgrazing and pollution). Biogeographical research done by Bădărău et al. (2001), in the Transylvania Depression underlined the negative influence of grazing, on the phytocenoses where there are present the populations of the three species mentioned above. Regarding the species Astragalus dasyanthus, in the case of the areas grazed by sheep, the authors noticed a numeric regression in the individuals of this species, the xerophile steppe phytocenoses being in the degradation and ruderalisation process. In the case of using the field as hayfield or pasture for the cattle, the populations of the species Astragalus dasyanthus are in general numerous, and the steppe vegetation is well preserved and the phytocenoses have high biodiversity.

According to Vicol (2009), because of the morphology of the oral appliance, the sheep can consume the plants at a distance less than $1 \mathrm{~cm}$ from the soil (in some cases even the underground parts), fact that reduces the capacity to remake/regenerate the plants and can lead to their disappearance in time.

The speed of reproduction in the species Astragalus dasyanthus by seeds, as well as vegetative ways in the laboratory is low (Ermolaev, 2007). Kožuharova et Firmage (2009) mention that the reproduction by seeds is reduced because: about $46 \%$ of the pollinated flowers form fruit and not all the mature ovules are transformed into seeds. In a low proportion, the flowers present the phenomenon of apomixis, the seedlings from these seeds having a very low rate of survival (Kožuharova et al., 2010), and the fruits and seeds can be destroyed by some insects (Kožuharova et Firmage, 2009).

According to Kožuharova et Firmage (2009), to preserve the populations of these species, it is important to protect the area where Astragalus dasyanthus grows and maintain the populations of pollinating insects (Bombus sp.). The results of the research regarding the germination of the seeds and the growth of the seedlings, done for the species Astragalus dasyanthus by Kožuharova et al. (2010), confirm the necessity to protect the native habitats, assuring thus its capacity of reproduction in situ.

According to Primack et al. (2002), the degrading of the vegetation by overgrazing determines the destruction of the ability of the vegetal communities to use the solar energy, leading to the reduction of the production of biomass and the 
number of the populations of animals dependent by food relations on certain vegetal species.

In the Plan of action of the European Union regarding biodiversity (2010), it is shown the fact that $65 \%$ of the protected habitats and $52 \%$ of the protected species are in a state of unfavourable preservation, more affected being the species in the meadows, the coast areas and the agricultural areas.

Boşcaiu underlined in 1985 the fact that "the only real possibility to protect the endangered species remains thus to try and preserve the biological communities and the ecosystems where they belong".

The presence of waste of packages in the protected area (cans of aluminium, PETs, bottles, paper packages). This waste determines modifications of landscape and visual discomfort.

Identification of some fire hearths (mainly on the slopes with S-SW exposure) resulted from burning the vegetal waste remained after cutting the black locust in autumn 2013 - winter 2014, fact that led to the destruction of the vegetal cover on some areas. The hearths represent a factor that can favor the process of soil erosion.

To all of these factors, it is added the climate changes in the latest years, which affects the conditions of habitat and implicitly the biological communities. The negative effects of the natural and anthropic factors can be combined, fact that determines their multiplication. We mention the fact that the threat to biodiversity has an effect also on society, which depends on the services of meadow ecosystem.

The facts presented above underline the insufficient involvement of the decisional factors in planning and implementing the measures regarding the preservation of the protected area.

\section{Conclusions}

The aspects presented above underlined for the period taken into account the existence of some negative anthropic influence on the protected area.

The effects of the anthropic factors identified (mainly the irrational grazing/overgrazing) consist in: modifications of the habitat with severe consequences (if appropriate measures are not taken) on the existence and perpetuation of the rare and vulnerable species included on the red lists and the degradation of the landscape.

\section{References}

Bancheva, Svetlana (2008), Taxonomic revision and population status of Psephellus marschallianus (Centaureinae, Asteraceae) in Bulgaria. Phytologia Balcanica, 14 (1), 57-60. 
Bădărău, Al. S., Dezsi, Ş., Comes, O. (2000), Cercetări biogeografice asupra speciilor stepice-silvostepice de Astragalus L. din Depresiunea Transilvaniei (I). Studia Univ. Babeş-Bolyai, Geographia, 45, 2, 117-130.

Bădărău, Al. S., Dezsi, Ş., Man, T. (2001), Cercetări biogeografice asupra speciilor stepice-silvostepice de Astragalus L. din Depresiunea Transilvaniei (II). Studia Univ. Babeş-Bolyai, Geographia, 46, 1, 51-67.

Boşcaiu, N. (1985), Criterii pentru constituirea şi gestiunea ecologică a rezervaţiilor botanice. Ocrot. Nat. Med. Înconj., 29, 2, 126-135.

Boşcaiu, N., Coldea, G., Horeanu, C. (1994), Lista roşie a plantelor vasculare dispărute, periclitate, vulnerabile şi rare din flora României. Ocrot. nat. med. înconj., t. 38 (1), Bucureşti, 45-56.

Collins, Emily. (2002) - Introduced Species Summary Project Russian Olive (Elaeagnus angustifolia L.) http://www.columbia.edu/itc/cerc/danoff-burg/invasion_bio/inv_spp_summ/Elaeagnus_angustifolia.htm (accesed 15.12.2014).

Costică, M. (2012), Planul de management al sitului ROSCI0117 Movila lui Burcel, 64 pp.

Dihoru, G., Dihoru, Alexandrina (1994), Plante rare, periclitate şi endemice în flora României - Lista roşie. Acta Bot. Hort. Buc. (1993-1994), 173-197.

Dihoru, G., Negrean, G. (2009), Cartea roşie a plantelor vasculare din România. Edit. Acad. Rom., Bucureşti, 630 pp.

Dobrescu, C., Leocov, M. (1982), Contribuţii floristice în rezervaţia "Movila lui Burcel" - Micleşti (jud. Vaslui). Culeg. Stud. Artic. Biol., Grăd. Bot. Iaşi. 2, 211-221.

Dumitriu-Tătăranu, I. (1960), Arbori şi arbuşti forestieri şi ornamentali cultivaţi în R.P.R., Ed. Agro-Silvică, Bucureşti, 337-338, 626-629.

Enescu, C. M., Dănescu, A. (2013), Black locust (Robinia pseudoacacia L.) - an invasive neophyte in the conventional land reclamation flora in Romania, Bulletin of the Transilvania University of Braşov, Series II: Forestry - Wood Industry - Agricultural Food Engineering, Vol. 6 (55) No. 2, 23-30.

Ermolaev, E. (2007), Research on conservation possibilities for Astragalus dasyanthus Pall. in the Republic of Moldova. Int. Master Programme Swedish Biodivers. Centre. Master theses No. 33, Uppsala, 21 pp.

Kožuharova, Ekaterina, Firmage, D. (2009), Notes on the reproductive biology of Astragalus dasyanthus Pall. (Fabaceae) a rare plant for Bulgaria. Comptes rendus de l'Académie bulgare des Sciences, 62, 9, 1079-1088.

Kožuharova, Ekaterina, Tzvetanova, Viktoria, Firmage, D. (2010). Seed germination and seedling development of two rare Astragalus species (Fabaceae). Phytologia Balcanica, 16, 1, 51-56.

Haralamb, A. (1967), Cultura speciilor forestiere. Ed. Agro-Silvică, Bucureşti: 709-743.

Horeanu, C., Cogean, I. (1981), Rezervaţii naturale şi monumente ale naturii din judeţul Vaslui. Vaslui, 50-53.

Irimia, Irina, Mânzu, C. (2013), Iris pontica Zapal. in Moldova's flora (Romania). An. Şt Univ „Al. I. Cuza” Iaşi, s. II a. (Biol. Veget.), 59, 1, 45-51. 
Kastler, Bernadette, Samimi, C. (2013), The Impact of Robinia pseudoacacia on Ground Vegetation and Plant Nutrient Matter in Donau-Auen National Park, $5^{\text {th }}$ Symposium for Research in Protected Areas, 10-12 June 2013, Mittersill, 345-352.

Katz, Gabrielle, Shafroth, P. B. (2003), Biology, ecology and management of Elaeagnus angustifolia L. (Russian olive) in Western North America, Wetlands, 23, 4, 763-777.

Mănoiu T (il.), Brânzan T (red.) (2013). Catalogul habitatelor, speciilor şi siturilor Natura 2000 în România. Fundaţia Centrul Naţional pentru Dezvoltare Durabilă. SC Exclus Prod S.R.L. \& R.A. Monitorul Oficial, Bucureşti, 425.

Negrean, G. (2001), Lista roşie a plantelor din România existente în pajişti (Inclusiv endemite şi subendemite) (Tracheophyta), in : Coldea Gh. et al. Ghid pentru identificarea şi inventarierea pajiştilor seminaturale din România. Edit. Alo, Bucureşti, 30-58.

Nyárády, A. (1957), Robinia L., in: Săvulescu T. (ed.). Flora Republicii Populare Romîne, V. Edit. Acad. R.P.R., Bucureşti: 245-250.

Oltean, M., Negrean, G., Popescu, A., Roman, N., Dihoru, G., Sanda, V., Mihăilescu, Simona (1994), Lista roşie a plantelor superioare din România. Studii, sinteze, documentaţii de ecologie. 1. Acad. Rom., Institutul de Biologie, 52 pp.

Oprea, Ad. (2005). Lista critică a plantelor vasculare din România. Edit. Univ. „Al. I. Cuza", Iaşi, 668 pp.

Pârvu, C. (2000), Universul Plantelor. Mică enciclopedie. Edit. Enciclopedică, Bucureşti, 581-582.

Pârvu C. (2005), Enciclopedia plantelor: plante din flora României. Vol. IV, Edit. Tehnică Bucureşti, 365-366.

Pricop, E., Negrea, B.-M., Gherghel, I., Popescu, I., E. (2010), The situation of Centaurea marschalliana Spreng. (Asteraceae: Centaureinae) population from "Movila lui Burcel" natural reserve (Vaslui county, Romania) and the negative impact in this protected area of religious buildings raised up inside the site. AES Bioflux, 2, 1, 91-96.

Primack, R. B., Pătroescu, Maria, Rozylowicz, L., Iojă, C. (2002), Conservarea diversităţii biologice, Ed. Tehnică, Bucureşti, 292 pp.

Prodan I., Nyárády E. I. (1964), Centaurea L., in: Săvulescu T. (ed.). Flora Republicii Populare Romîne, IX. Edit. Acad. R.P.R., Bucureşti, 785-951.

Sârbu, I., Chifu, T. (2003), Lista roşie a plantelor vasculare din Moldova. Mem. Secţ. Şt., ser. IV, 24 (2001), 131-151.

Sârbu, I, Ştefan, N, Oprea, Ad. (2013). Plante vasculare din România: determinator ilustrat de teren, Edit. victorBvictor, Bucureşti, $1320 \mathrm{pp}$.

Sîrbu, C. (coord.), Oprea, Ad. (2011), Plante adventive în flora României. Edit. „Ion Ionescu de la Brad", Iaşi, 181-187, 207-210.

Vicol, Ioana (2009), Factori cu impact negativ asupra habitatelor din cadrul Rezervaţiei Biosferei Retezat. Ecos, 21, 15-20.

$* * *$, Legea nr. 5/2000 - Privind aprobarea Planului de amenajare a teritoriului naţional Secţiunea a III-a -zone protejate - http://www.mmediu.ro/beta/wp-content/uploads/2012/07/201207-26_legislatie_arii_protejate_legea5din2000amenajareteritoriuzoneprotejate.pdf $15.12 .2014)$

(accesed 
***, OM MMDD nr. 1964 din 13 decembrie 2007- Privind instituirea regimului de arie naturală protejată a siturilor de importanta comunitară, ca parte integrantă a reţelei ecologice europene Natura 2000 în România http://www.mmediu.ro/app/webroot/uploads/files/2012-07-

25_legislatie_arii_protejate_ordin1964din2007scinatura2000\%281\%29.pdf (accesed 15.12.2014)

***, OUG 57/2007 - http://www.batlife.ro/wp-content/uploads/2010/03/doc_02_OU_257_20071.pdf (accesed 15.12.2014)

***, Planul de acţiune al UE privind biodiversitatea: Evaluare 2010 http://ec.europa.eu/environment/nature/info/pubs/docs/2010_bap_ro.pdf (accesed 15.12.2014)

***, (2013), Raport naţional privind starea mediului - anul 2012. Ministerul Mediului şi Schimbărilor Climatice, Agenţia Naţională pentru Protecţia Mediului, Bucureşti http://www.anpm.ro/anpm_resources/migrated_content/uploads/116008_RSM-2012.pdf

(accesed 15.12.2014)

***, Elaeagnus - http://www.issg.org/database/species/ecology.asp?si=216\&fr=1\&sts=sss\&lang=EN (accesed 15.12.2014)

***, Robinia $-\mathrm{http} / /$ www.issg.org/database/species/ecology.asp?si=572\&fr=1\&sts=sss\&lang=EN (accesed 15.12.2014) 